\title{
INCREASING THE BUSINESS POTENTIAL OF COMPANIES BY ENSURING CONTINUITY OF THE DEVELOPMENT OF THEIR INFORMATION SYSTEMS BY CURRENT INFORMATION TECHNOLOGIES
}

\author{
Milena TVRDÍKOVÁ \\ Department of Applied Informatics, VSB-Technical University of Ostrava, \\ Faculty of Economics, Sokolská třída 33, 70121 Ostrava, Czech Republic \\ E-mail: milena.tvrdikova@vsb.cz
}

Received 11 May 2013; accepted 27 August 2013

\begin{abstract}
This paper deals with applications of information and communication technologies in the management of companies and institutions. It also focuses on Competitive Intelligence and Business Intelligence and the description of their position in business management. The paper presents current trends in information and communication technologies with emphasis on the use of virtualization and Cloud Computing technologies. The author discusses the importance of Cloud Computing to maintain the continuity of information system of enterprises with low financial impact, thereby increasing its stability. Theoretical framework and literature support the assumption that information and communication technologies are essential for the competitiveness of small and mediumsized enterprises. Discussed are factors that affect management and use of information and communication technologies in small and medium-sized enterprises, in particular the use of cloud computing. Based on the results obtained from a questionnaire survey carried out in the Czech Republic, the author proposed methodological recommendations to facilitate the transition to cloud computing.
\end{abstract}

Keywords: information systems, business intelligence, corporate performance management, competitive intelligence, small and medium-sized enterprises, strategic management, virtualization, cloud computing.

JEL Classification: D22, O33, L86.

\section{Introduction}

Industrial society is changing into a society where information and knowledge play the key role. We can observe the emergence of a global information infrastructure that processes and transfers an increasing amount of data and information.

There is a growing pressure on timeliness, quality, relevance, reliability and the amount of transmitted information. A significant shift taking place in companies is the shift in priorities to strategic management and increased demand on the flexibility of companies and institutions. Managers and executives are exposed to an unprecedented information 
pressure. As a result, they need adequate tools. Such tools are based on the application of information and communication technologies (ICTs).

The ability to make correct decisions concerning the deployment and use of ICTs has become integral to successful management. The integration of information, communication and multimedia technologies brings about the emergence of new business opportunities that will play a key role in the economy and in public life in the coming decades.

\section{Defining the issue}

Information Systems (IS) and ICTs have become the backbone for conducting business in many fields (Vrana 2005). The quantity of tools offered in the field of ICTs is growing exponentially, making it difficult to understand them. The term ICTs is used to describe all the techniques involved in information processing (i.e., hardware (HW), telecommunication equipment as well as appropriate software (SW) and organizational structure). There is an increasing dependence between IS and business capabilities. Changes in strategy, rules, and business processes require changes in HW, SW, datastorage sites and telecommunications equipment. Frequently, if a company wants to do something, it depends on what information technology allows (Sodomka 2006).

It is difficult to ensure the continuity of IS development, especially in small and medium-sized enterprises (SMEs) and institutions. One of the main causes are the financial demands that it entails. The SME segment is very important for the European Union, representing $99 \%$ of all companies and institutions in the EU. The survey defines the SME segment in accordance with the definition published in the Official Journal of the European Union L 124 of 2003.

ICTs can be used to increase competitiveness, enable businesses to create new jobs, as well as increase productivity and sales through access to new markets. The above mentioned effects have been examined by many researchers, e.g. (Qureshi, Kamal 2011). By using ICTs, SMEs can also compete with other larger firms and also effectively contribute to the enlargement of supply chains.

While much has been written about the possibilities offered to SMEs by adopting ICTs, little has been done in the area of business models that allow using the ICTs to enhance competitiveness (Qureshi, Kamal 2011). In this sense, companies may find the costs of ICTs unacceptable, their benefits not always BEING clear (Matthews 2007).

The author works with the assumption that one of the ways to ensure the continuity for the innovation of an information system in an SME is an approach based on the use of Cloud Computing (CC) services.

\section{Specification of the role of information systems in managing companies and institutions}

The stability of companies and institutions requires them to be flexible so that they can quickly and effectively adapt to external changes. If a company is not able to adapt to rapidly changing conditions, the management is not able to return the behaviour of the 
socio-economic system to the steady state, and the existence of the company or institution is in danger.

Flexible system of management acquires the necessary information. It is must find out in due time the type and extent of information which is to be collected, properly and effectively processed, distributed and used (Tvrdikova 2008). This can be ensured only through an efficient information system.

Information system and system control are intertwined and penetrate each other. One thing is common to them - they ensure equilibrium in the behaviour of companies and institutions. Information systems currently include the following components:

- $H W$ - computer systems of various types and sizes, to be completed with the necessary peripherals that are interconnected, if necessary, through a computer network and connected to a memory subsystem to manage large volumes of data.

- $S W$ - the systems programs controlling the computer as well as programs allowing to effectively work with data, programs enabling the computer system to communicate with the real world and application programs that are intended for specific classes of tasks of certain user classes.

- Orgware - consisting of a set of standards and regulations that define the rules of operation and use of information systems and ICTs. Peopleware - related to the quality of conditions for adaptation and for efficient functioning of humans in computer environment assigned to it.

- Real world (changes in the social and political environment, information resources, legislation, standards, scientific and technological development) - the context of information system.

In today's ISs, ICTs play an important role due to their ability to affect different sectors of the economy. The key is not the technology itself, but the possibility of its application. In this context, Hagell refers to three waves (Hagell et al. 2004). The first wave is the technology, the second wave is the possibility to transfer knowledge, and the third wave includes the possibility to use the infrastructure and knowledge. Thus, research cannot be limited only to the development of new technologies but also focused on their application.

According to the level of management, the role of ICTs can be assigned as shown in Table 1.

Firms and institutions have been struggling with the availability of capital for continuous innovation and the operation of ISs. This problem persists especially among SMEs. A frequent cause of problems is also lack of information the management and employees of SMEs have about the benefits of high quality ICTs. It is therefore necessary to increase managers' awareness of the possibilities of ICTs in supporting their decision making and to find ways to facilitate the implementation of new ICTs in practice.

Entrepreneurs and managers who work in the public and non-profit sector currently have access to a considerable amount of data available from a variety of sources. When they want to make decisions, they need tools that help them process data to obtain 
Table 1. The role of ISs and ICTs in management systems

\begin{tabular}{|c|c|c|c|c|}
\hline $\begin{array}{c}\text { Management } \\
\text { level }\end{array}$ & Objective & Meaning & Tools & $\begin{array}{l}\text { Reasons for not } \\
\text { using ICTs }\end{array}$ \\
\hline Operative & $\begin{array}{l}\text { Integration of } \\
\text { sub-functions } \\
\text { of the entire } \\
\text { company }\end{array}$ & $\begin{array}{l}\text { Support for key } \\
\text { company functions and } \\
\text { processes - production, } \\
\text { (internal) logistics, } \\
\text { human resources and } \\
\text { economics }\end{array}$ & $\begin{array}{l}\text { ERP applications } \\
\text { forms the core } \\
\text { of IS }\end{array}$ & $\begin{array}{l}\text { Unaffordable } \\
\text { in relation to } \\
\text { the needs of the } \\
\text { company (small } \\
\text { business) }\end{array}$ \\
\hline Tactical & $\begin{array}{l}\text { Maintaining } \\
\text { internal stability } \\
\text { of the system. } \\
\text { Knowledge of } \\
\text { the situation } \\
\text { in their own } \\
\text { company }\end{array}$ & $\begin{array}{l}\text { Tracking the } \\
\text { organization's correct } \\
\text { progress towards the } \\
\text { target }\end{array}$ & $\begin{array}{l}\text { BI application, } \\
\text { specifically focused } \\
\text { on decision-making } \\
\text { support. Analysis of } \\
\text { the situation in their } \\
\text { own company }\end{array}$ & $\begin{array}{l}\text { Lack of awareness } \\
\text { of the potential } \\
\text { benefits of BI. } \\
\text { Concerns about } \\
\text { the financial costs }\end{array}$ \\
\hline Strategic & $\begin{array}{l}\text { Checking the } \\
\text { relevance of } \\
\text { a company's } \\
\text { or institution's } \\
\text { objectives }\end{array}$ & $\begin{array}{l}\text { Evaluating information } \\
\text { and acquiring } \\
\text { knowledge }\end{array}$ & $\begin{array}{l}\text { Application of } \\
\text { CPM and CI } \\
\text { methods and } \\
\text { strategic analysis } \\
\text { and synthesis tools }\end{array}$ & $\begin{array}{l}\text { Lack of awareness } \\
\text { of the potential } \\
\text { benefits of CI. } \\
\text { Concerns about } \\
\text { the financial costs }\end{array}$ \\
\hline
\end{tabular}

the necessary information - Business Intelligence (BI) applications (Tvrdikova 2013). They allow an analysis of the situation in their own company or institution and ensure access to information from the company's external environment. They allow warning against threats or highlight new business opportunities. In order to support the strategic information management, there are specific applications such as Corporate Performance Management (CPM) and methods for Competitive Intelligence (CI).

\section{Corporate performance management and competitive intelligence}

$\mathrm{CPM}$ is a managerial approach that can be used to monitor and manage the performance of the whole company through IT (see Fig. 1).

The main purpose of CPM is not to see how an organization performs, but how to improve its performance. It provides answers focused on the future (Nowadays, CPM is also called Enterprise Performance Management, Business Performance Management, Strategic Performance Management or Performance Management).

$\mathrm{CI}$ domain is to answer the question of whether the company has identified the correct objective. CI can be defined as a set of the following activities: definition, collection, analyses and distribution of information and knowledge about clients, competitors and about other aspects of the external environment surrounding the company or institution. This process is called "early signal analysis" (Molnar 2009) and allows early identification of risks and opportunities in the market before they become obvious. 
Many different methods and tools have been created and tested for strategic analysis and synthesis (e.g. BCG matrix, GE matrix, Porter's five force analysis, SWOT analysis, macroeconomic analysis). All these methods have one thing in common - they require information from a variety of information sources. The position of CPM and CI in the management of companies and institutions is shown in Figure 2.

CI has primarily been the domain of medium and large companies that operate on a global scale. Their resources allow them to invest into ICTs and into staff that carry out the CI agenda. Reasons for unexploited CI potential in SMEs are insufficient knowledge of potential benefits from the implementation of CI and the fear of a financially demanding activity that requires a lot of staff commitment and investment in expensive IT tools

CI has primarily been the domain of medium and large companies that operate on a global scale. Their resources allow them to invest into ICTs and into staff that carry out the CI agenda. Reasons for unexploited CI potential in SMEs are insufficient knowledge of potential benefits from the implementation of CI and the fear of a financially demanding activity that requires a lot of staff commitment and investment in expensive IT tools.

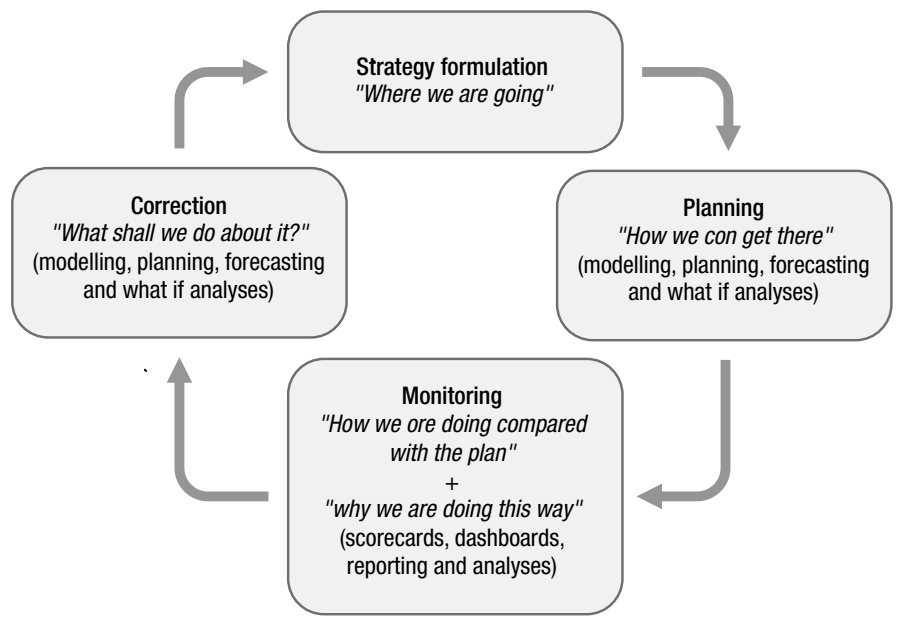

Fig. 1. Four basic steps of CPM (source: designed by the author)

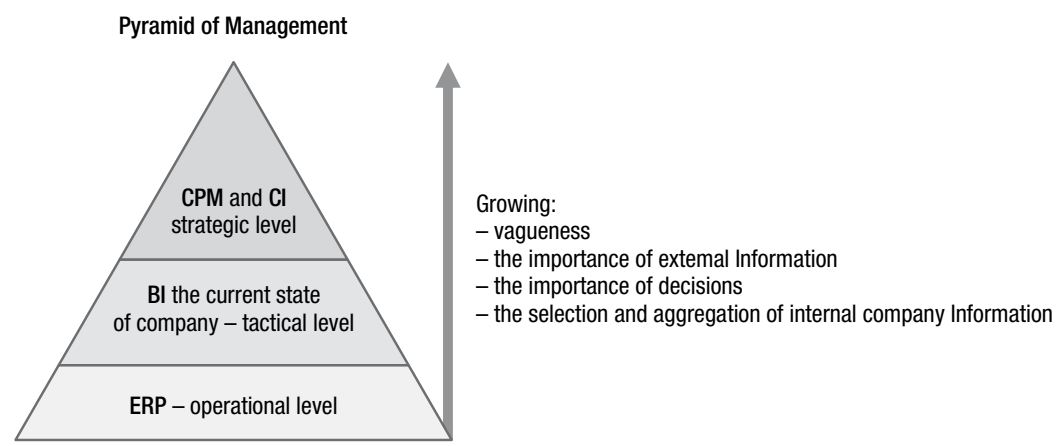

Fig. 2. The position of CPM and $\mathrm{CI}$ in the management of companies and institutions 


\section{Trends in ICTs}

Extending virtualization of all layers of infrastructure as a proven technology and a reliable connection of users to communication networks greatly encourage the development of information technologies (Foldyna 2012).

The development of an enterprise IS/ICTs is strongly influenced by the following current technological trends:

- Storage virtualization and consolidation - allows reducing the number of physical data servers while increasing their resilience to failures. It provides easy scalability. Virtualization of computing capacity provides a greater flexibility in obtaining higher computing performance. When not needed, its computational capacity can be reduced or disconnected.

- Desktop virtualization - it can improve security, simplify management and support compliance with standards.

- Standardization and transparency of business processes - greater flexibility and optimization of the core activities in enterprises can be achieved while reducing costs and demands on management, maintenance and development.

- Increased performance and mobility of individual applications and services - for companies and organizations whose management or supervisory activities migrate among several centres. Virtualization tools allow moving virtual machines that are in operation without interrupting the service. They can ensure the transfer of entire applications instead of local execution. Virtualization tools allow moving virtual machines running with no interruption of service. This allows changing the configuration and facilitate upgrade of hardware and software while in operation.

Current trends in ICT services related to the management of companies and organizations (Sevcik 2012):

- Process management companies and their ICT - efforts to uniquely and effectively link ICTs with the business model, corporate culture and business processes.

- Strengthening the relationship between business and ICT. Managing the business IT relationship on the basis of IT services.

- Use of scalable ICTs services.

- Division of responsibilities for the benefits and costs of ICTs between business managers and ICT managers.

- Increasing the share of external ICT service supplies - in various forms (standard outsourcing, services of an Application Service Provider or CC (see Chapter 5).

- Continuity of IS - important in view of the linkages between IT and other aspects implemented processes, services etc. (Rozehnal 2013).

Trends in ICTs and ICT services are summarized in Table 2. 
Table 2. Trends in ICTs and ICTs services

\begin{tabular}{ll}
\hline \multicolumn{1}{c}{ Technology trends in ICTs } & \multicolumn{1}{c}{ Trends in ICT services } \\
\hline $\begin{array}{l}\text { Virtualization - of storage, of computing } \\
\text { capacity, of desktop }\end{array}$ & Support for business process management \\
\hline Standardization, flexibility & $\begin{array}{l}\text { Managing the business-ICT relationship based } \\
\text { on services }\end{array}$ \\
\hline $\begin{array}{l}\text { Increasing mobility and the performance } \\
\text { of applications and services }\end{array}$ & Using scalable services \\
\hline Focus on the quality of mobility & Increasing the share of CC services \\
\hline
\end{tabular}

\section{Cloud computing}

The NIST (National Institute of Standards and Technology 2015) definition of Cloud Computing version 15 (Mell, Grance 2015) emphasizes the Essential. Characteristics: on-demand self-service, broad network access, resource pooling, rapid elasticity and measured service.

Cloud computing is defined as a model for enabling convenient, on-demand network access to a shared pool of configurable computing resources (e.g., networks, servers, storage, applications, and services) that can be rapidly provisioned and released with minimal management effort or service provider interaction. This cloud model promotes availability and is composed of five essential characteristics, three service models, and four deployment models.

\section{Service models (distribution models) are categorized according to the services offered:}

SaaS - It is the principle of sharing software licenses installed on the server of the service provider with other users of this service. Customers are provided with applications that are accessible anytime and from anywhere. The current commonly used SaaS uses multi-tenant architecture in which the application is designed to serve multiple users and businesses. The service provider has administrative control over applications. He is responsible for its updating, installation, maintenance and safety.

PaaS - Platform as a Service is a model providing complete resources for developing and maintaining custom applications available through the Internet. Unlike SaaS, PaaS does not involve renting already created applications; conversely, the customer develops its own ones. Disadvantages of PaaS include large dependence on the provider.

IaaS - Infrastructure as a Service offers the computing infrastructure in the desired configuration in a virtualised form. Customers are provided with a virtual hardware that may function as a complete ICT infrastructure. The provider is responsible for the delivery of the ordered computing power and its connection via a network. The customers then install the operating system and install everything themselves according to their requirements. Basically, it involves renting the hardware in an agreed configuration. IaaS price is formed depending on the provided RAM, CPU, storage size and connectivity. The advantages of using IaaS are zero hardware acquisition costs and very low upgrade costs. 
Sometimes you can come across an all-embracing term "IT as a service" (XaaS), which may include all the above mentioned models.

\section{Typical CC deployment scenarios - models can also be classified by ownership:}

Public cloud - Services are offered and shared among non-cooperating users. Public cloud is suitable for SMEs, having obsolete IT and wanting to save, as well as SMEs intending to expand their IT but not knowing what volume of IT services they will really need. It is also suitable for SMEs that want to increase the availability of their own IT, but do not want to pay higher costs for transfer, as well as for SMEs or large companies that want to transfer part of the capital costs to operating costs.

Private cloud - provided within an organization and usually this organization is its owner and administrator. This form is suitable for medium or large companies that require a large number of changes in infrastructure, or for medium or large companies that want to streamline their IT operations, evaluate their real price for business and provide services to internal customers. The purpose of the private cloud is the ability to offer software as a service to their employees or cooperating third parties and utilize their own hardware more efficiently.

Hybrid cloud - a combination of the two above approaches. It is suitable for an association of companies that want to operate a common IT to reduce their costs but require maintaining a certain degree of autonomy for each company.

Community cloud - the model consists in an association of funds owned by a certain group of people (community) who have similar interests or want to use the same services. This community retroactively provides services to the same group, e.g. gaming, dedicated servers.

\section{Pros and Cons of CC solution:}

Thanks to the CC services, users need no knowledge of the technologies, they nor manage their operation. Access to applications and data located on a server is facilitated through a web browser; there are no special hardware requirements. Applications or services are provided from centralized data centres via network. The provider assumes the responsibility for the implementation, security and monitoring, audit and compliance as well as for maintenance and support. The provider is also responsible for capacity planning and release management of sources.

$\mathrm{CC}$ also has environmental benefits in terms of reduced energy consumption and emissions. This reduction is the result of (Hajek 2010) better-utilized servers; a single server is able to ensure the simultaneous operation of several companies, thanks to infrastructure sharing. Another benefit is a flexible using of other computing resources such as the CPU, memory and data storage according to current needs. It is a considerable space to reduce emissions and energy consumption through increasing the efficiency of data centres (energy losses, inefficient cooling, unnecessary disk array operation, etc.). Pros and cons of CC usage are shown in Table 3: 
Table 3. Pros and cons of CC usage

\begin{tabular}{ll}
\hline \multicolumn{1}{c}{ Advantages } & \multicolumn{1}{c}{ Disadvantages } \\
\hline $\begin{array}{l}\text { Significant reduction of investments in IT } \\
\text { Infrastructure }\end{array}$ & $\begin{array}{l}\text { A risk of failing of permanent operation via } \\
\text { the Internet - reliability }\end{array}$ \\
\hline $\begin{array}{l}\text { Price transparency, the user pays only } \\
\text { for what was used (pay-per-use) }\end{array}$ & $\begin{array}{l}\text { Increased costs for the transfer of large volumes } \\
\text { of data }\end{array}$ \\
\hline $\begin{array}{l}\text { Lower price, the provider rents the resources } \\
\text { to multiple users (multi-tenancy) }\end{array}$ & $\begin{array}{l}\text { Concerns about the security of sensitive data } \\
\text { and data }\end{array}$ \\
\hline $\begin{array}{l}\text { Self-service ordering IT services (catalogue) } \\
\text { Users are not required to know the technology, } \\
\text { nor manage its operation alone }\end{array}$ \\
$\begin{array}{l}\text { Rapid implementation of service, flexible } \\
\text { specification of the services }\end{array}$ \\
\hline $\begin{array}{l}\text { Scalability and elasticity, computing power } \\
\text { becomes a commodity that we buy as needed }\end{array}$ \\
$\begin{array}{l}\text { Providers assume responsibility for all } \\
\text { the components of the service }\end{array}$ \\
\hline $\begin{array}{l}\text { Environmental benefits - reduced energy } \\
\text { consumption and emissions }\end{array}$ \\
\hline
\end{tabular}

Often-discussed issue is the security in virtualized environments. When considering the use of CC in the IS of a company, concerns about the safety are associated with fears of a different approaches to sensitive data and to safety between different states of the EU (described in the Data Protection Directive, also in PCI DSS) and the USA (described in FISMA, HIPAA, and SOX). There are also differences among individual EU Member States (Foldyna 2012). No one has made a full analysis with reference to the experience of already completed projects. Overall IT security is described in survey (Pitner, Ministr 2015).

The authors' own survey carried out in the Czech Republic and Poland showed that a significant part of business owners and managers as well as end users is aware of the existence of $\mathrm{CC}$; however, most of them still do not trust it or have no idea what CC brings (Hanclova 2015).

\section{Survey of IT use to support SME activities in the Moravian-Silesian region}

Many other surveys in the Czech Republic and abroad show that SMEs can consider some wider use of ICT useful for the increase of financial efficiency and competitiveness (Mikolas et al. 2011). If SMEs desire the investment to ICT, they should cooperate with an advisor in order to ensure the balance between ICT and strategic goals of the enterprise. 
The results of surveys together with my own experience from cooperation with SMEs in the Czech Republic were a motivation to conduct my own survey of IT use in SMEs of Moravian-Silesian Region. The survey aimed to determine the level of familiarity with ICT options and the use of IT services. The data was collected electronically. CC was also related.

The research was focused on classification of entities with respect of their approach to ICTs usage and the determination of main factors influencing ICT use and acquisition. The secondary goal was to find the degree of SME familiarity with possibilities of CC.

The sample consisted of 112 respondents. 101 of them were SMEs from three sectors: manufacturing (28), retail (19) and services (54). These respondents were from micro companies (22), small businesses (34) and medium enterprises (45). Clarity and meaningfulness of the questionnaire was checked in a pilot study. Part of the results from the survey is shown in Table 4.

Table 4. IT use to support SME activities in the Moravian-Silesian region - survey results

\begin{tabular}{|c|c|c|c|}
\hline Area & Tools used & Underused tools & Acquisition method \\
\hline $\begin{array}{l}\text { Personal } \\
\text { IT and } \\
\text { communication } \\
\text { tools }\end{array}$ & $\begin{array}{l}\text { E-mail, office tools, } \\
\text { antivirus and compression } \\
\text { tools are used routinely } \\
\text { in most companies. Also } \\
\text { extensively used are } \\
\text { groupware tools }\end{array}$ & $\begin{array}{l}\text { Instant messaging is } \\
\text { nearly absent }\end{array}$ & $\begin{array}{l}\text { Noticeable tendency to use } \\
\text { open source programs }\end{array}$ \\
\hline $\begin{array}{l}\text { External } \\
\text { relation } \\
\text { management }\end{array}$ & $\begin{array}{l}\text { E-shops (about } 10 \% \text { ) used } \\
\text { Main usage by trading } \\
\text { companies }\end{array}$ & $\begin{array}{l}\text { E-procurement, } \\
\text { e-marketplace, mobile } \\
\text { business }(88 \%) \text { not used. } \\
\text { But there is growing } \\
\text { interest by the } \\
\text { m-business }\end{array}$ & $\begin{array}{l}\text { Through paid e-trade } \\
\text { applications and use } \\
\text { of open source programs }\end{array}$ \\
\hline
\end{tabular}

\begin{tabular}{|c|c|c|c|}
\hline ERP & $\begin{array}{l}\text { Most respondents work } \\
\text { with an ERP system; } \\
\text { however, they differ as to } \\
\text { the number and type of } \\
\text { modules used }\end{array}$ & & $\begin{array}{l}\text { The way ERP modules } \\
\text { are acquired and the } \\
\text { responsibility for their } \\
\text { maintenance are surprising. } \\
\text { There is a significant } \\
\text { proportion } \\
\text { of applications developed } \\
\text { using } \\
\text { the companies' own means } \\
\text { and they predominantly } \\
\text { use their own employees } \\
\text { to perform maintenance }\end{array}$ \\
\hline $\begin{array}{l}\text { Analytical } \\
\text { tools }\end{array}$ & $\begin{array}{l}\text { BI tools, data } \\
\text { warehousing or data } \\
\text { marts are not widespread, } \\
86 \% \text { of respondents } \\
\text { indicate minimal usage. } \\
\text { Most companies use data } \\
\text { warehouses }(20 \%)\end{array}$ & $\begin{array}{l}\text { Comprehensive BI } \\
\text { solutions are rare, which } \\
\text { is probably caused by } \\
\text { insufficient awareness } \\
\text { of these products and by } \\
\text { their price }\end{array}$ & $\begin{array}{l}\text { Data warehouses - mostly } \\
\text { licensed. } \\
\text { The use and expansion } \\
\text { of BI tools, however, } \\
\text { continues to grow, mainly } \\
\text { based } \\
\text { on open source programs }\end{array}$ \\
\hline
\end{tabular}


End of Table 4

\begin{tabular}{|c|c|c|c|}
\hline Area & Tools used & Underused tools & Acquisition method \\
\hline $\begin{array}{l}\text { Tools to } \\
\text { manage } \\
\text { company } \\
\text { performance }\end{array}$ & $\begin{array}{l}\text { BPM (Business Process } \\
\text { Management applications) } \\
19.4 \% \\
\text { Applications for corporate } \\
\text { performance management } \\
(\mathrm{CPM})-(17 \%) \text { in } \\
\text { manufacturing companies }\end{array}$ & $\begin{array}{l}\text { Usage of BPM tools } \\
\text { is not sufficient } \\
\text { in manufacturing } \\
\text { enterprises. } \\
\text { It is better in companies } \\
\text { providing services. }\end{array}$ & $\begin{array}{l}\text { They mostly include } \\
\text { buying licenses }\end{array}$ \\
\hline Other software & $\begin{array}{l}\text { Statistical software and } \\
\text { CAD for manufacturing } \\
\text { enterprises (rarely) }\end{array}$ & & $\begin{array}{l}\text { Lack of information about } \\
\text { other ICT applications }\end{array}$ \\
\hline
\end{tabular}

As regards $\mathrm{CC}$, the results are consistent in all types of SMEs. The largest share of the respondents $(47 \%)$ do not have any idea about the benefits of this relatively new technology. A significant portion of respondents are familiar with the technology (22\%). Many of them expressed their distrust of the technology and consider it to be unusable at present. On the contrary, there is a small percentage of respondents who are interested in the $\mathrm{CC}$ and are planning to deploy it soon or are already using a $\mathrm{CC}$ application.

The preferred software features are: reliability, flexibility, consistency, followed cost, speed and additional services with the same preferences.

\section{Recommendations for transition to $\mathrm{CC}$ technologies}

The paper follows with methodological recommendations for the process of transition to $\mathrm{CC}$ technologies, which help to ensure IS continuity in SMEs and institutions with relatively low financial cost.

CC services are an appropriate solution for many SMEs and institutions that play an important role in today's business world. SMEs need to be able to reduce the costs associated with data processing. The Internet of Things generates huge amounts of data from more than 30 billion connected machines, buildings, sensors and objects (Pochyla 2015). HW needs to be upgraded and maintained. SW needs to be updated and implemented, and its support must be provided. CC allows accessing data stored on servers of the CC service provider via the Internet. These services offer the possibility to avoid a significant one-off investment in the IT infrastructure. The price is a transparent, payper-use item with no hidden costs. $\mathrm{CC}$ involves a fundamental change in the way that IT services are provided, being one of the ways how to cope with a reduced budget.

\section{Recommendations steps of the transformation process:}

1. Feasibility study (see Table 5). The study should not be limited to economic issues. The transition must bring positive changes for end users and this must be emphasized. The study can also be ordered from an independent consultancy.

2. Provider selection. One or more suppliers can be chosen; however, while negotiating the terms and conditions, it is necessary to allow the possibility to change the sup- 
Table 5. Transition of IT companies to cloud computing

\begin{tabular}{lll}
\hline \multicolumn{1}{c}{$\begin{array}{c}\text { Feasibility study - content } \\
\text { (to be drawn up by company } \\
\text { or an independent consultant) }\end{array}$} & $\begin{array}{c}\text { Selection of CC service } \\
\text { supplier (selection criteria) }\end{array}$ & $\begin{array}{c}\text { CC from user's } \\
\text { perspective }\end{array}$ \\
\hline Analysis of current situation & Service transparency & Types of users \\
\hline Target solution concept & Reliability of suppliers & User expectations \\
\hline $\begin{array}{l}\text { Economic assessment of the current and } \\
\text { target state of IT operations }\end{array}$ & $\begin{array}{l}\text { The availability of all } \\
\text { components of the service }\end{array}$ & $\begin{array}{l}\text { Mobilization of } \\
\text { internal company } \\
\text { resources }\end{array}$ \\
\hline The list of positive changes for end users & $\begin{array}{l}\text { Flexibility and integration } \\
\text { possibilities }\end{array}$ & \\
\hline Risk management plan & & $\begin{array}{l}\text { Thorough training } \\
\text { and motivating users }\end{array}$ \\
\hline $\begin{array}{l}\text { The schedule of works for a transition } \\
\text { to CC - migration project proposal (we } \\
\text { recommend migrating in successive steps) }\end{array}$ & & \\
\hline
\end{tabular}

plier of individual services. Before the final decision on the supplier, collect all the necessary information.

3. Information about the service transparency. The customer has the right to know the HW the service runs on, what applications and databases are used and what the plans for the future expansion of services are. An important factor is the physical location of services - CC stores the data and applications in a specific data centre. It is therefore important to know where the services are operated, especially with regard to compliance with legislative conditions such as those for accounting systems or the processing of personal data which is subject to fairly restrictive conditions in the EU.

4. Reliability of the supplier. Important factors in determining the supplier's reliability are the time the provider has been in business, the number of employees, references by existing customers and whether it guarantees availability and high quality SLA (Service Level Agreement). Flexibility of the provider in dealing with problems and responding to questions (e.g. how long it takes the company to respond after a request is sent) is also important. Companies may be accommodating at first; but it is not enough. References by other customers are helpful in this respect. A technical survey can be used to check the status of technologies and technological potential of the provider's company, the SW and HW used, the skills of their staff and measures taken in case of an accident. The provider should allow the customer to perform regular framework audits of the services provided. It should have guidelines for such audits. The greatest fear of many companies is having to leave their data at the mercy of a third party. The security of the services is in the provider's interest, it is necessary to choose a trusted provider with a good reputation, which complies with the industry's security standards (ISO, certification, etc.).

5. Availability of all components of the service. The value of the availability of services from the provider should not fall below a threshold of $98 \%$. It means, seven days downtime on the infrastructure due to maintenance and unexpected problems are 
considered. Otherwise, everything runs continuously. Accessibility is a very important thing, especially if the user requires continuous access for customers and partners.

6. Information about the flexibility of services and the possibilities for integration. Many CC use an API (Application Programming Interface) that allows integrating with other applications as well. This way, possible gaps in functionality can be filled. CC service providers usually continuously extend the functionality and possibilities of their infrastructure. Easy integration with the environment seems suitable, so that users can easily and effectively manage available resources.

7. Transition to CC should mean a positive change for all types of end users as well.

A characteristic feature of $\mathrm{CC}$ is ordering IT services as self-service, selecting a service from a standardized offer (service catalogue), automated service order, preparation of provisioning, service implementation, possibility to pay-per-use and the possibility to flexibly specify implementation models (the services are both public and private). Each cloud environment includes processes that perform the processing of a user request, where the user's role is indispensable. Integrating the CC technology with email systems and directory services are fundamental requirements for any CC solution. Processes within the approval workflow can be very precisely mapped to IT processes and user roles. In addition to standardization and automation, users get a uniform and consistent approach to IT services.

User roles are reduced in public CC services. Typical public CC users use the services occasionally. As service consumers, they generally use infrastructure services (IaaS, PaaS model), or the SaaS model for office activities and communication (e-mail, chat, VoIP). Currently, there is a wide range of CC services that are available to these users, in many cases free of charge.

$\mathrm{CC}$ end users' workplaces remain essentially unchanged (common PCs). However, one of the current IT trends is desktop virtualization, which forms the basis of CC desktop. Users continue to work with their favourite operating system and applications, but the actual operation of the system with applications is run centrally in a data centre and the users' operating system and applications are displayed on their monitors. The advantage is higher stability and resistance to failure and the ability to share the virtual desktop on a PC as well as on a number of mobile devices. A disadvantage is the need for a stable network with a sufficient throughput. PCs can be replaced with terminals whose administration is more efficient and cheaper than the administration and maintenance of PCs.

Innovation through the transition to the $\mathrm{CC}$ also helps to mobilize internal company resources. This involves the correct and effective use of the potential of all people involved, strengthening employees' loyalty and commitment. Innovation is subject to corporate culture. It strongly reflects the way people are managed, how the company communicates and motivates its employees.

The use of these methodological recommendations enables entrepreneurs and managers in companies and institutions to ensure the continuity of the development of their IS, which is now a precondition for maintaining SMEs stability. Increasing the availability of relevant information and the possibility to carry out competent analyses increases 
the quality of management and competitiveness of these companies. Also, public and non-profit organizations can get the ability to analyse the situation, to avoid risks to their activities and on the other hand discover available new opportunities.

Managers are poorly informed about the constantly evolving IT. They still prefer to purchase the licensed applications. Some of them use open source resources.

\section{Conclusions}

The quality of information systems and the ability of entrepreneurs and managers to utilise their potential with the help of ICT affects the competitiveness of companies and institutions.

A survey conducted among companies showed that managers now have a huge amount of data, but are unable to process them without the support of ICT. It turned out that SMEs often use only personal IT and communication tools. Other results involved a finding that SMEs continue to have insufficient resources for IT investments as well as lack of awareness about the possibilities to purchase quality IT with lower costs.

Suitable topic for future research is outsourcing, especially technologies of cloud computing.

Another topic is the development of analytical tools, whose use does not require deep knowledge of statistical methods and ICT.

Other surveys may focus on the development of new methodologies for innovation systems. These guidelines should be designed specifically for entrepreneurs and managers.

\section{Acknowledgment}

The results in the paper are based on findings of a research, project SP2011/112, Faculty of Economics, VSB-TU Ostrava, Czech Republic, 2011, by the European Social Fund within the project CZ.1.07/2.3.00/20.0296 and also by Operating Program EU CZ.3.22/3.3.04/12.02994 2013.

\section{References}

Foldyna, P. 2012. Cloud není revoluce, ale evoluce [Cloud is not a revolution, but evolution] [online], [5 February 2015]. Available from Internet: http://www.systemonline.cz/

Hagell, I. J.; Brown, J.; Davidson, L. 2004. The power of pull: how small moves, smartly made. Can set big things in motion. New York: Basic Books.

Hajek, P. 2010. Cloud computig v praxi: je cloud computing opravdu ekologický? [Cloud computing in practice: Is cloud computing really ecological?] [online], [26 March 2012]. Available from Internet: http://www.itbiz.cz

Hanclova, J; Rozehnal, P.; Ministr, J.; Tvrdikova, M. 2015. The determinants of IT adoption in SMEs in the Czech-Polish border areas, Information Technology for Development 21(3): 426444. http://dx.doi.org/10.1080/02681102.2014.916249

Matthews, P. 2007. ICTs assimilation and SME expansion, Journal of International Development 19(6): 817-827. http://dx.doi.org/10.1002/jid.1401 
Mell, P.; Grance, T. 2015. National Institute of Standards and Technology - NIST - 2015. The NIST definition of Cloud computing version 15 [online], [5 February 2015]. Available from Internet: http://nvlpubs.nist.gov/nistpubs/Legacy/SP/nistspecialpublication800-145.pdf

Mikolas, Z.; Peterkova, J.; Tvrdikova, M. 2011. Konkurenční potenciál prưmyslového podniku [The competitive potential of the industrial enterprise]. Praha: C.H. Beck. ISBN 978-80-7400$379-0$

Molnar, Z. 2009. Competitive intelligence. Praha: Oeconomica.

Pitner, T.; Ministr, J. 2015. Security aspects of PaaS cloud, in $11^{\text {th }}$ International Conference on Strategic Management and its Support by Information Systems (SMSIS2015), May 21-May 22, 2015, Uherské Hradiště, Czech Republic [CD]. Ostrava: VSB Technical University of Ostrava, 463-469.

Pochyla, M. 2015. Internet of things: big challenge for enterprises, in $11^{\text {th }}$ International Conference on Strategic Management and its Support by Information Systems - SMSIS2015, May 21-May 22, Uherské Hradiště, Czech Republic [CD]. Ostrava: VSB Technical University of Ostrava, 470-477.

Qureshi, S.; Kamal, M. 2011. Role of cloud computing interventions for micro-enterprise growth: implications for global development, in Proceedings of the Fourth Annual SIG GlobDev Workshop, 3 December, 2011, Shanghai, China, 2-25 [online], [cited 26 March 2012]. Available from Internet: http://www.globdev.org/files/Shanghai\%20Proceedings/16\%20REVISED\%20 Qureshi\%20Role\%20of\%20Cloud\%20Computing.pdf

Rozehnal, P. 2013. Aspects of approach to application IS/IT in SMES, in $21^{\text {th }}$ Interdisciplinary Information Management Talks - IDIMT-2013. 42: 121-128. ISBN 978-3-99033-083-8.

Sevcik, F. 2012. Jak vybírat cloud [How to select a cloud], IT Systems 1-2 [online], [26 March 2012]. Available from Internet: http://www.systemonline.cz/virtualizace/cloud-cena-az-nadruhem-miste.htm

Sodomka, P. 2006. Informační systémy v podnikové praxi [Information systems in enterprise practice]. Brno: Computer Press.

Tvrdikova, M. 2008. Aplikace modernich informačních technologii v řizeni firmy: Nástroje ke zvyšování kvality informačnich systémü [Application of modern information technologies in business management: tools to increase the quality of information systems]. Praha: Grada Publishing. Tvrdikova, M. 2013. Increase in the competitiveness of SMEs using business intelligence in the Czech-Polish border areas, in Federated Conference on Computer Science and Information Systems - FeDCSIS 2013, Krakow. IEEE Computer Society, Conference Publishing Services, Los Alamos, 981-984. ISBN 978-1-4673-4471-5.

Vrana, I. 2005. Zásady a postupy zaváděni podnikových informačnich systémů: praktická př́ručka pro podnikové manažery [Principles and procedure for introduction of enterprise ISs: A practical quide for enterprise managers]. Praha: Grada.

Milena TVRDÍKOVÁ, an Associate Professor, graduated in Economics at the Institute of Chemical Technology, Prague (1971) and finished PhD studies of Management Theory at VSB-TU Ostrava in 1992. She habilitated in Business Informatics at Technical University of Ostrava. She deals with Designing Information Systems, Software Applications, Human Factor of Computer Systems, System integration, Business Intelligence, Integrated Management Systems of Enterprises. The author of 5 books and many papers in this branch. Member of the board of Czech Society for System Integration and vice-chair of EUNIS-CZ (European University Information Systems of Czech Committee). 